\title{
Fogo pálido e o inacabamento
}

\author{
Luis Henrique Boaventura* \\ Ernani Cesar de Freitas ${ }^{\star \star}$
}

\section{Resumo}

Este trabalho explora as noções de inacabamento a partir do romance Fogo pálido (2004), de Vladimir Nabokov (1994, 2004, 2009, 2010), constituinte de nosso corpus de pesquisa. Como marco teórico, toma-se por base o dialogismo de Mikhail Bakhtin (1997) e as postulações de Pierre Lévy $(1998,2002)$ quanto ao hipertexto. A pesquisa é descritiva e tem caráter qualitativo. $\mathrm{O}$ inacabamento será abordado por diferentes - embora convergentes - pontos de vista. O inacabamento será abordado enquanto aspecto inerente ao dialogismo e ao hipertexto, do inacabamento literal do pensamento de Bakhtin (o que leva ao inacabamento que é próprio da filosofia, necessário para ser sempre continuado através da leitura), do inacabamento da obra de Nabokov (cujo último livro, $O$ original de Lau$r a$, de 2009, permaneceu incompleto) e do inacabamento presente em Fogo pálido (2004); como a mesma ideia de inconcluso refrata-se em diferentes prismas para voltar a combinar-se, finalmente, em face de um sintetizador comum: o infinito.

Palavras-chave: Inacabamento. Hipertexto. Dialogismo.

\section{Introdução}

A análise de Fogo pálido (2004) feita neste texto segue três diferentes inacabamentos da ordem da vida e da obra de Nabokov (1994, 2004, 2009, 2010), ficando estes à sombra, ainda, de um quarto: o inacabamento da leitura, que dribla os muros impostos pelos pontos finais e pelas últimas páginas para se refugiar nas referenciações infinitas do hipertexto. Segundo essa iniciativa, foi formulada uma questão norteadora: de que modo estão relacionados os diferentes sentidos do inacabamento em Vladimir Nabokov? Há uma intrigante trama de coincidências históricas que

\footnotetext{
Mestrando em Letras pela Universidade de Passo Fundo. E-mail: luis@consultordetextos.com.

** Doutor em Letras pela PUCRS, com pós-doutorado em Linguística Aplicada e Estudos da Linguagem (PUC-SP/ LAEL); pesquisador nas áreas Linguagem e Trabalho, Semântica Argumentativa, Semiolinguística; professor do Programa de Pós-Graduação em Letras da Universidade de Passo Fundo; professor do Programa de Pós-Graduação em Processos e Manifestações Culturais da Universidade Feevale, Novo Hamburgo - RS. E-mail: ecesar@upf.br.
}

Data de submissão: fev. 2013 - Data de aceite: abr. 2013 http://dx.doi.org/10.5335/rdes.v9i1.3537 
enlaçam, como é comum aos grandes escritores, a vida do artista à sua arte. O objetivo deste estudo é analisar, com cautela, as ligações entre esses inacabamentos que ligam a obra e a vida do escritor russo, e para isso realizamos um diminuto recorte do trabalho de quase 50 anos de Nabokov. Tomamos como corpus de análise o livro Fogo pálido, publicado originalmente em 1962. A opção por essa obra deve-se ao fato de ela realizar um espelhamento preciso com o mundo real do escritor, além de possuir uma estrutura profundamente hipertextual. O marco teórico situa-se no dialogismo de Bakhtin (1997) e nas ideias de Lévy $(1998,2002)$ quanto ao hipertexto, aos quais se somam as contribuições de Brian Boyd (1991, 1999), o mais importante biógrafo de Nabokov. A pesquisa é descritiva, bibliográfica e de caráter qualitativo. $\mathrm{O}$ artigo divide-se em quatro partes: "1 Inacabamento: Lévy e o hipertexto" traz as postulações do filósofo sobre a hipertextualidade que servem de base a este trabalho, juntamente com o dialogismo, tema em " 2 Inacabamento: Bakhtin e o dialogismo", no qual trazemos as ideias sempre atuais do filósofo e linguista russo com um aprofundamento em Fogo pálido e em seu autor. "3 Inacabamento: Nabokov e os castelos de areia" evoca uma aplicação mais efetiva da hipertextualidade e do dialogismo na análise do livro, enquanto "4 Inacabamento: a palidez da (ou de quem) chama" reagrupa os eventos extra e intradiegéticos para tentar esclarecer algumas escolhas de Nabokov por trás de seu flerte antigo com o inconcluso.

Fogo pálido, publicado em 1962, é o décimo terceiro romance de Vladimir Nabokov. O livro (traduzido no Brasil por Jorio Dauster e Sérgio Duarte), a exemplo deste artigo, divide-se em quatro partes: "Prefácio", "Fogo pálido (Um poema em quatro cantos)", "Comentário" e "Índice remissivo". "Fogo pálido" é um poema escrito pelo grande poeta americano John Francis Shade. Com a morte de Shade (assassinado por engano), a obra, planejada para ter mil versos, fica incompleta, com 999. Charles Kinbote, seu amigo e vizinho pelos últimos meses de sua vida, toma posse dos manuscritos de "Fogo pálido" e decide publicá-lo. O resultado desta publicação é formalmente (a despeito apenas do nome de Nabokov na capa) o livro que acaba nas mãos do leitor: há o prefácio, escrito por Kinbote; o poema, escrito por Shade; a longa análise do poema, escrita por Kinbote; e, ao final, um índice remissivo. O leitor descobrirá muito cedo que Kinbote pertence à nobre linhagem dos narradores inconfiáveis e que seu "Comentário", que analisa o poema quase verso a verso, parece antes discorrer sobre si mesmo do que sobre Shade e sua "obra-prima". Kinbote se convence de (e empreende esforços para convencer o leitor) que "Fogo pálido" narra, na verdade, sua própria história. Kinbote seria Charles II, vulgo "o Bem-Amado", rei exilado de um país nórdico chamado Zembla. Apesar das referências que Kinbote enxerga em cada 
traço do poema de Shade, não há sequer uma menção a Zembla ou a seu rei em toda a extensão de "Fogo Pálido".

No caso de interpretar Fogo pálido como um libelo de Vladimir Nabokov contra a crítica e o academicismo parasita que toma a arte como frívolo objeto de análise para arruiná-la em suas pormenorizações, que mais confundem do que esclarecem (como na má sorte do sapo, que deve, necessariamente, morrer para ser dissecado e estudado), então, a simples intenção de analisá-lo acusa um paradoxo. Entretanto, não se pode passar pela inocência de ignorar a figura de Nabokov, um intelectual, acadêmico, professor de literatura obcecado por James Joyce e, acima de tudo, um escritor, como tantos, extremamente vaidoso e competitivo. Fogo pálido clama pela análise crítica e teórica em todas as suas rupturas, sua narrativa experimental e sua estruturação fragmentária, mas também posta-se em atenção para zombar de qualquer um que se voluntarie a fazê-lo. Brian Boyd, o mais importante biógrafo de Nabokov, após publicação de Nabokov's pale fire: the magic of artistic discovery (1999), foi chamado (e admitiu, não sem distinto bom grado, haver sentido na comparação) de um duplo extradiegético de Charles Kinbote, o alucinado e alucinante narrador de Fogo pálido. $\mathrm{O}$ "Kinbote's Kinbote", como o chamou o crítico Ron Rosenbaum (1999a, 1999b). Nesse sentido, o romance de Nabokov é a própria compostura de uma armadilha ontológica, um aparelho de elaborada prestidigitação; o diálogo que Nabokov mantém com as estruturas de romance e crítica, com a história da literatura e com a relação entre esta e a academia prevê que o leitor de Fogo pálido não saia livre de ser pego em contradição, o mais vexatório dos pecados da retórica.

Apesar disso, convém considerar que, se houve risco na abordagem e entrega à invenção de uma nova concepção de romance que poderia muito bem ter naufragado monumentalmente, parece pouco prescrever que deveria haver, também, por parte do leitor, ao menos uma fração desse apetite, uma sede desse mergulho, uma queda premeditada; afinal, é este o pedido inaudível implícito não apenas em Fogo pálido como em todo contrato entre leitor e escritor, aprendiz e alquimista: que se largue docemente o corpo ao redemoinho do seu caldeirão de bronze.

\section{Inacabamento: Lévy e o hipertexto}

Lendo um artigo em uma página qualquer, "identifico" uma palavra que me chama a atenção e que me leva a outro texto. Nesse texto, "abro" uma passagem em que um segundo autor é citado. "Procuro" pela fonte da referência, "leio" o capítulo em questão, "volto" ao texto anterior, "esclareço" a dúvida que aquela palavra me havia despertado e "retorno", finalmente, ao primeiro texto. "Alcanço" meu objetivo imediato, mas, mesmo assim, não "finalizo" minha leitura; apenas 
a coloco em modo de espera, fibrilando, até que eu volte a recorrer, em algum momento, a todas as palavras-chave, a todos os conceitos, a todas as janelas que "deixei" de abrir em minha primeira, segunda e terceira leitura.

A página referida na primeira linha não é, contudo, uma página de internet. Não necessariamente. A hipertextualidade, como sabemos, é interior, cognitiva. O processo de leitura nunca é linear, tampouco o processo de escrita: apenas sua estrutura final pode ser disposta de tal forma, mas a mecânica que deu origem ao mais linear dos textos depende de conexões que cortam caminhos; fia-se de sinapses e de atalhos. $O$ hipertexto, do modo como o tratamos hoje, constituído e explícito no hyperlink digital, na palavra que brilha entre as outras e que ganha relevo como que acusando a carga de direções que possui quando clicada, é tão somente a exteriorização de processos que realizamos muito antes que sequer se pudesse pensar em fibra ótica.

O hipertexto, a hipermídia ou a multimídia interativa percorrem um processo já antigo de artificialização da leitura. Se ler consiste em selecionar, esquematizar, construir uma rede de remissões internas ao texto, em associar a outros dados, em integrar as palavras e as imagens para uma memória pessoal em reconstrução permanente, então os dispositivos hipertextuais constituem uma espécie de reificação, de exteriorização dos processos de leitura (LÉVY, 1998) ${ }^{1}$.

De que fala Pierre Lévy já falava Jorge Luís Borges $(2007,2009)$ nos contos Livro de areia e A biblioteca de babel, odes ao inconcluso, ao que não pode ser selado, ao que não pode ser contido, ou seja: à própria leitura. $\mathrm{O}$ hipertexto digital é a materialização do sonho borgiano, em suas faltas e virtudes, trazendo em seu centro a lemniscata que rege a vazão do sorvedouro. É com a assombrosa visão do infinito que nos deparamos ao olhar de frente a internet, esse monstro de espelhos paralelos, e é à vertiginosa ideia de um espaço sem fim, que não pode jamais ser acabado (ao contrário de quase tudo, incluindo nossas próprias vidas), que falam Borges (2007, 2009), Cortázar (2009) e Nabokov (2004); Lévy (1998, 2002), Foucault (1987) e Bakhtin (1997).

A ideia de inacabamento assombra a obra do russo com a mesma intensidade com que assombrou os dois argentinos. A construção hipertextual de Fogo pálido, publicado em 1962, não se limita ao simulacro do modelo de hipertextualidade; Nabokov cria um romance em que o texto dribla a barreira física das folhas para concebê-lo em um quadro liquefeito, em que a primeira página confunde-se com a última sem que 296 delas interponham-se em seu caminho. E Nabokov desenha essa premissa de modo explícito: o poema "Fogo pálido" foi planejado para ter mil versos, mas seu autor John Shade é assassinado antes de poder terminá-lo, deixando-o incompleto, com exatamente 999 versos. Charles Kinbote, porém, alega saber que o verso $\mathrm{n}^{0} 1.000$ seria idêntico ao primeiro, "Eu era o pássaro abatido, sombra" (NABOKOV, 2004, p. 31). 
A noção de hipertexto vem prenhe da de inacabamento. Segundo Irene Machado, "inacabamento é assim o princípio estético a partir do qual é possível considerar a poiesis do dialogismo como campo conceitual da estética bakhtiniana e do modelo artístico do mundo" (2010, p. 84). A progressão hipertextual não possui fim, apenas pausa; definição primária do dialogismo bakhtiniano. Seja por base de um princípio estético, como ocorre em Fogo pálido, seja pela força do inacabamento inerente ao próprio dialogismo, a verdade é que os textos que encontramos são todos inconclusos, porque assim é o próprio ser humano em relação a outro no mundo.

Enquanto redobramos o texto sobre ele mesmo, produzindo assim sua relação consigo mesmo, sua vida autônoma, sua aura semântica, nós o reportamos também a outros textos, a outros discursos, a imagens, a sentimentos, a toda a imensa reserva flutuante de desejos e de signos que nos constituem. Aqui, não é a unidade do texto que está em jogo, mas a construção de nós mesmos, construção sempre a refazer, inacabada (LÉVY, 1998) $)^{2}$.

Se é pela alteridade que se homologa a identidade, é perfeita a afirmação de Pierre Lévy (1998) ao final de seu artigo: "nós somos o texto". Uma rede de conexões infinitas, um aparelho de remissões, um plano cartográfico dos labirintos do conhecimento. Como ocorre em Fogo pálido e como ocorre na vida, é na relação com o outro que se lavra o hipertexto. $\mathrm{E}$ se falamos de alteridade, se falamos da relação entre "eu" e "outro", falamos de dialogismo; logo, falamos de Bakhtin.

\section{Inacabamento: Bakhtin e o dialogismo}

Há um princípio essencialmente dialógico correndo toda a extensão de Fogo pálido. O conceito do dialogismo tem origem na análise de discurso e regeu as reuniões do Círculo de Bakhtin entre 1919 a 1929, assim como toda a linguística pelos olhos do filósofo russo. Conforme Charaudeau e Maingueneau, o dialogismo "se refere às relações que todo enunciado mantém com os enunciados produzidos anteriormente, bem como com os enunciados futuros que poderão os destinatários produzirem" (2008, p. 160). Para Bakhtin, todo falante é em algum nível um respondente, pois reside em sua voz, adormecida, a presença inaudível de todas as vozes já ouvidas:

Todo falante é por si mesmo um respondente em menor ou maior grau: porque ele não é o primeiro falante, o primeiro a ter violado o eterno silêncio do universo, e pressupõe não só a existência do sistema da língua que usa, mas também de alguns enunciados antecedentes - seus e alheios - com os quais o seu enunciado entra nessas ou naquelas relações (baseia-se neles, polemiza com eles, simplesmente os pressupõe já conhecidos do ouvinte). Cada enunciado é um elo na corrente complexamente organizada de outros enunciados (BAKHTIN, 1997, p. 272).

Nabokov desenha em seu romance uma estrutura de preceitos estreitamente dialógicos, polifônicos e, em última instância, intertextuais. Temos, abrindo o livro, o prefácio assinado por Charles Kinbote, autoproclamado editor de Fogo pálido e amigo íntimo de seu autor. $\mathrm{Na}$ 
sequência, há o poema "Fogo pálido", de John Shade, o genial poeta americano assassinado por engano pouco antes de poder completar sua obra. Então, voltamos a Charles Kinbote com a segunda parte, "Comentário", que toma pouco mais de 200 páginas das 298 que o livro possui. Kinbote retoma os versos do poema para anotar-lhes o estilo, a marca poética de seu autor, os jogos de palavras, mas logo começa a divergir e narrar o que parece ser sua própria história a culminar com o trágico assassínio de seu amigo. Por fim, a inclusão de um índice remissivo.

Fogo pálido é inteiro um diálogo entre Charles Kinbote e John Shade. Charles Kinbote expressa grande proeminência do comentador sobre o comentado e do delírio sobre a realidade. Se cada livro é um ponto luminoso no universo da literatura, dialogando em algum nível com toda a história que o precede (como a luz dos astros dialoga com a faísca primitiva do Big Bang), Fogo pálido é, antes de qualquer coisa, um comentário sobre esse painel. Principalmente se considerarmos que Nabokov era levemente passional em relação ao trabalho de James Joyce (lecionava literatura em Princeton e Cornell, e apropriava-se do escritor irlandês seguidamente como objeto de suas aulas. Há certeza de que Thomas Pychon frequentou a classe de Nabokov nessa mesma época) e que Fogo pálido é, em muitas formas, uma resposta à prosa labiríntica de Ulysses e Finnegans wake ${ }^{3}$. Todo escritor dialoga com seus heróis; Nabokov não apenas procedeu a esse diálogo como tratou de fotografá-lo.

Desde o primeiro momento, Charles Kinbote dá sinais de sua ação centrípeta e destrutiva sobre a obra de John Shade, mesmo se ele acreditasse que a natureza de seus atos é nobre: o de evitar que uma obra-prima perca-se condenada à mudez que o fogo sentencia (que se anote aqui a forma escolhida para a destruição, pelo incendiar dos manuscritos originais, pois ela voltará a aparecer de modo central neste trabalho). O prefácio encerra-se sob uma máxima que assombrará todo o livro: "para bem ou para mal, é o comentador que tem a última palavra" (NABOKOV, 2004, p. 25). Trata-se de uma nota de Nabokov à relação do escritor com seu público (entendido aqui em âmbito geral: editores, professores, críticos literários ou "simples leitores"). Porque assim é a obra depois de publicada: ela expõe um autor já morto e entrega seu corpo à fome dos carniceiros. $\mathrm{O}$ autor possui pouca ou nenhuma força sobre a leitura que seu público fará de sua obra depois que esta deixa seus arquivos para ganhar o mundo. Qualquer tentativa de complementação é vista como "authorial trespass" (violação que o autor faz de sua própria obra depois de já assimilada pela cultura popular). A revelação feita por Nabokov, em uma entrevista realizada em 1973, de que Kinbote teria cometido suicídio após o término do livro causou, ao contrário do que se poderia imaginar, pouco ou nenhum efeito entre seus leitores. 
Quando um entrevistador perguntou a Nabokov sobre 19 de outubro, data em que Kinbote assina seu prefácio, ele identificou-o como "o dia em que Kinbote cometeu suicídio (e ele certamente o fez depois de dar seus últimos retoques para sua edição do poema)". Michael Wood trata disto como "authorial trespassing", e comenta: "nós não devemos prestar atenção a isso" (BOYD, 1999, p. 106, tradução nossa) $)^{4}$.

Há, contudo, algumas referências a esse sentido nas próprias páginas de Fogo pálido (a mais clara na nota ao verso 1.000 , a última, que diz "minhas notas e eu próprio estamos chegando ao fim"). Mesmo assim, é interessante ver $\mathrm{Na}$ bokov pego em sua própria armadilha: ele tenta dialogar com sua obra, tenta emitir uma sentença, uma resolução, um pitaco que seja, mas é rejeitado. Afinal, como ele mesmo anota em Fogo pálido, "é o comentador que tem a última palavra". E a palavra de Nabokov, nesse caso, é vista como o suspiro de um fantasma, um débil reflexo post-mortem.

Importante notar, e Bakhtin joga luz definitiva sobre esse aspecto, que o enunciado (no âmbito do "diálogo real") conclui-se, mas o dialogismo, jamais. $\mathrm{O}$ dialogismo bakhtiniano é perpétuo, iniciado no verbo do Adão mítico e continuado, certamente, para muito depois de termos morrido até um suposto fim dos tempos (parece correto, inclusive, que início e fim dessa rede encantada de enunciados só passem a ser concebíveis pelo prisma de dois livros bíblicos). Todo diálogo sob essa perspectiva, para além de sua "conclusibilidade específica" (BAKHTIN, 1997, p. 275), é inacabado por natureza. Por isso é permitido a Charles Kinbote comentar sobre a obra de Shade: o poema "Fogo pálido" está dialogicamente inacabado; na falta do último verso, há apenas uma nota metalinguística de Nabokov, uma manifestação literal da ideia. Kinbote pode responder ao poema o quanto quiser, assim como a crítica respondeu aos livros de Nabokov. $\mathrm{O}$ escritor resigna-se ao lugar do autor morto, aquele cujos originais ficarão à mercê de olhos que se prostrarão sem demora a julgá-los, distorcê-los e interpretá-los à sua revelia.

Condenado ao fadário do autor impotente sobre sua obra, além de John Shade e Vladimir Nabokov (de quem falaremos em específico a seguir), esteve, também, o próprio Mikhail Bakhtin. Grande parte da obra do russo permaneceu inacabada, vindo a público em compilações e edições reorganizadas por terceiros. João Vianney Cavalcanti Nuto explica o inacabamento do próprio legado e do pensamento de Bakhtin.

Por uma combinação de temperamento com circunstâncias da vida, Bakhtin é um pensador ensaísta. [...] Existe, em Bakhtin, aquele inacabamento circunstancial, derivado das dificuldades tanto de produção como de publicação de sua obra. Assim, boa parte de sua obra recuperada é formada por rascunhos; ensaios concluídos, mas não preparados para publicação; esboços; anotações e apontamentos (2009). ${ }^{5}$

O próprio Bakhtin fala sobre o caráter de inconclusibilidade de sua obra em texto que integra Estética da criação verbal. "Em meus trabalhos, há muito inacabamento externo, um inacabamento que 
se deve menos ao próprio pensamento do que ao modo de expressão e de exposição" (BAKHTIN, 1997, p. 387). O texto em questão, "Apontamentos 1970-1971", vem acompanhado de duas convenientes anotações em itálico, feitas a posteriori: "Texto de arquivos, não revisado pelo autor" e "Notas preparatórias para uma obra global que não foi realizada".

A beleza do inacabamento em Bakhtin, assim como em Nabokov, é que ele somente pode ser remediado pela leitura. Para além de lamentar o inevitável, lamentar que grandes filósofos e escritores não sejam capazes de firmar um acordo faustiano que estenda suas vidas ao mesmo diâmetro de suas obras, deveríamos celebrar a continuidade que $\mathrm{o}$ inacabamento assegura. $\mathrm{O}$ inacabado gera leitura por necessidade, porque é preciso perseguir uma solução, mesmo que não definitiva, mas mais adequada que a atual. $\mathrm{O}$ inacabamento do pensamento de Bakhtin e da obra de Nabokov, bem como de toda a filosofia e a literatura, salvaguarda sua continuidade através de outras mentes, que, apesar de igualmente inconclusas, serão capazes de oferecer respostas e (o que é mais importante) perguntas diferentes.

Reside no inacabamento de uma ideia sua transmissão através do tempo, assim como reside no inacabamento de Fogo pálido seu estranho fascínio por mais de 50 anos. Consta na habilidade do grande escritor gerar perguntas para as quais somente é possível dar respostas que provocam sem nunca satisfazer.

\section{Inacabamento: Nabokov e os castelos de areia}

Certa vez, alguém disse que correr as páginas de um romance é como correr um castelo encantado, pródigo naquilo em que só os castelos da imaginação possuem em sua planta: passagens secretas. Por força de sua natureza (seu encantamento), essas passagens levam tanto a antessalas no interior do castelo quanto a mundos nunca antes pressupostos de dentro de seus muros. Porém, a hipertextualidade não é uma propriedade extracorpórea, não veio ao homem com a espontaneidade misteriosa dos fenômenos da natureza. Hipertexto diz respeito, antes, a propriedades inerentes ao ser humano, o que significa afirmar que o mapa dessas alamedas reais não está inscrito em pedra ou sequer teve seu projeto lavrado por terceiro; ele é reflexo do mapa cognitivo de quem lê, daguerreótipo da mecânica de leitura do indivíduo, impossível de ser apreendida, impossível de ser preservada, desfazendo-se entre os dedos como um pergaminho milenar.

Há janelas permanentes no castelo, sem dúvida; mas a maioria delas muda de lugar, desaparece em um quarto para reaparecer em outro, ou, então, para perderem-se para sempre. Nabokov desenha um projeto de leitura logo no início de Fogo pálido. 
Embora essas notas, como é de praxe, apareçam depois do poema, aconselha-se ao leitor consultá-las primeiro e em seguida ler o poema com o auxílio delas, relendo-as, é evidente, à medida que avançar no texto; terminado o poema, talvez seja aconselhável consultá-las uma terceira vez, de modo a completar o quadro. Considero conveniente nesses casos, a fim de eliminar o estorvo de folhear o livro para frente e para trás, cortar e grampear as páginas junto com o texto do poema, ou, o que é ainda mais simples, comprar dois exemplares da obra e colocá-los lado a lado numa mesa confortável (NABOKOV, 2004, p. 25).

Essas são as janelas permanentes, os guiões de leitura (tais como ler linearmente, voltar a certo capítulo se assim for determinado pelo narrador etc.). É notável que Nabokov chegue a sugerir uma ruptura da própria mídia "livro", reestruturando-o, pelo ato de "cortar e grampear as páginas", em um novo monumento do qual o leitor, e não mais autor ou diagramador ou editor, é o artífice. Retomando Lévy, "a partir de uma linearidade ou de uma superficialidade inicial, rasgar, ferir, entortar, redobrar o texto, para abrir um meio vivo onde possa desplugar-se o sentido [...]" (2002, p. 2). Porque qualquer remissão explícita dispara um link de memória no leitor, que o fará ziguezaguear pela plataforma de leitura, não raro projetando-o, também, para o futuro. $O$ trecho que consta na página 83, “pequenos, mas genuínos fantasmas espectrais das conversas sobre Zembla e seu infortunado rei", oferece, como um presságio, um piscar de olhos sobre o devir da história, o destino final do "rei" de quem fala Kinbote. A palavra "infortunado" é, em si mesma, uma janela, um momento de vidência.

Há, por outro lado, as janelas móveis. Passagens que somente eu, em razão de minha visão de mundo e minha bagagem cultural (logo, minha individualidade), posso atravessar. Em primeiro lugar, posso escolher seguir ou não as diretrizes dispostas pelo narrador Charles Kinbote. Na primeira página da segunda parte, "Comentário", Kinbote prescreve: “[...] mas um jovem jardineiro de New Wye, no qual eu estava interessado (ver nota aos versos 997-998), [...]" (NABOKOV, 2004, p. 75, grifo nosso). Caso decida interromper a continuidade demarcada pelo dígito da página e saltar ao comentário sobre os versos 997 e 998, estarei simplesmente pulando 200 páginas do romance, aproximando-me (por assim dizer, perigosamente) de seu "final" (trata-se do penúltimo comentário de Kinbote antes do índice remissivo). Nabokov deixa evidente o que, é verdade, talvez nem precisasse assim de tanta evidência: o fato de que há tantos modos de se ler um livro quanto há de escrevê-lo. Minha individualidade, portanto, determinará que o caminho que percorrerei ao ler um livro (não apenas um exemplar evidentemente hipertextual como Fogo pálido) é único, irrepetível e, mais do que nunca, indeterminável pelo autor ou por qualquer outra entidade pretensamente numinosa que se intrometa no universo da minha leitura.

Em segundo lugar, na leitura de qualquer texto, é possível encontrar 
passagens que o autor não imaginou deixar para serem encontradas. Elas, de fato, não estão dispostas no texto; são interiores, são passagens que atravesso no processo íntimo de leitura. $\mathrm{Na}$ página 93 de Fogo pálido, por exemplo, é possível que me flagre subitamente intrigado por "árvore do gênero Carya". Em outros tempos, poder-se-ia recorrer a uma enciclopédia ou a um dicionário de botânica; hoje, recorre-se a um buscador qualquer para descobrir que Carya é um gênero botânico que pertence à família Juglandaceae. O caminho, certamente, apontaria para a página seguinte (no caso, a definição de "Juglandaceae"), e assim indefinidamente, porque assim é o texto: ele nos oferenda com maleáveis passagens de luz. O discurso levado a cabo por Charles Kinbote é um painel ocelado para o panorama de suas frustrações, suas ideologias, suas vaidades; por isso suspeitamos tanto de sua conduta, por isso deciframos níveis da trama à revelia do narrador, única fonte de informação de que Nabokov nos provém. As palavras, como pequenas queimaduras de cigarro, expõem no texto uma porosidade relativa; é às vezes opaco; às vezes, limpo e translúcido como a luz do meio-dia.

Não há medida concebida pelo homem para o volume de possibilidades que se abrem na leitura de um romance. As passagens acessíveis em um texto vão muito além das previamente construídas por seu autor, estabelecendo-se pela individualidade de quem lê, fundindo-se umas às outras, mudando de lugar em conformidade com o humor, com a disposição, com o tempo (alguns dirão que jamais se lê o mesmo livro duas vezes, ao menos não sem a ocorrência de um lapso razoável de tempo; a leitura nos reflete, incluindo nossas transformações). Essa ideia de movimento, com prioridade sobre a ideia de rigidez - de algo que é fluido, ora descrito na metáfora da água, ora na da areia, não por acaso imagens igualmente relacionáveis ao próprio tempo -, passa por Borges, é lógico, mas também se repete em Pierre Lévy. Porque o hipertexto obedece ao que é imaterial, incorpóreo, inespecífico, ou seja, ao virtual. Ao fluxo do pensamento. "A partir do hipertexto, toda leitura é uma escritura potencial. Mas sobretudo os dispositivos hipertextuais e as redes digitais desterritorializaram o texto. Eles fizeram emergir um texto sem fronteiras próprias, sem interioridade definível. Existe agora o texto, como se diz da água ou da areia" (LÉVY, 1998, grifo nosso). ${ }^{6}$

A página da Wikipédia, ou de um site especializado em botânica, ou de uma empoeirada enciclopédia, é sempre a página de um mundo externo ao castelo de cartas marcadas para o qual o livro me dá entrada. As palavras (assim como unidades semânticas maiores) são janelas tanto para dentro quanto para fora do universo diegético, e seu efeito, embora planejado e dirigido pelo autor, não pode ser controlado. A lapidação do verbo é sempre parcial, sempre inacabada. 
É esse inacabamento que, lincando Nabokov a Bakhtin e a John Shade, abre novos planos de leitura como um pentagrama abre andares entre os mundos. É o inacabamento presente tanto filosófica quanto literalmente por toda a obra de Bakhtin; é o inacabamento o termo regente de Fogo pálido, pela "impresença" marcante e desesperadora de John Shade; e, mais recentemente, como se comprovou e como se verá, foi o inacabamento que, como obra de um deus entediado e zombeteiro, ditou o réquiem de Vladimir Nabokov enquanto artista. Ao que parece, não há história que valha a pena contar sem um corte de poética ironia.

\section{Inacabamento: a palidez da (ou de quem) chama}

- 1950: Vera, esposa de Nabokov até $o$ fim de sua vida, salva os manuscritos de Lolita que o escritor começava a queimar no quintal de casa.

- 1959: Charles Kinbote, amigo e vizinho do poeta americano John Francis Shade, vê de sua varanda o atormentado escritor ateando fogo aos manuscritos de "Fogo pálido".

- 1977: doente, Nabokov pede à esposa que queime os manuscritos de $O$ original de Laura, caso morra antes de concluí-lo.

Há entre esses três eventos uma série de janelas, atalhos que fazem saltar da ficção à realidade e de um ponto no tempo a outro. Em primeiro lugar, por óbvio, a recorrência do gesto: a destruição pelo fogo, força purificadora, limpando na natureza o velho para abrir espaço ao novo; ou seja, um agente da transformação. Queimam-se os restos de uma obra como se queimam os restos mortais de um homem; não se distinguirá, posteriormente, um punhado de cinzas do outro. Em segundo lugar, a vulnerabilidade do homem no momento do gesto. A saúde debilitada de Nabokov em 77, os últimos dias de vida de um John Shade assombrado pelo suicídio da filha em 59 e a depressão de Nabokov em 1950. ${ }^{7} \mathrm{O}$ episódio consta na biografia de Nabokov escrita por Brian Boyd (1991), Vladimir Nabokov: the american years.

Mesmo as considerações financeiras iriam
certamente obrigá-lo a escrever algo que ele
pudesse vender para o New Yorker. Talvez
chegara o momento de abandonar a coisa
toda [a literatura]. Desanimado, ele carre-
gou sua pilha de fichas até o incinerador do
jardim posto sobre a grama na parte de trás
do número 802 da Rua East Seneca. Neste
momento, felizmente para Nabokov e para
a literatura, sua mulher o interrompeu e
pediu-lhe para repensar sua decisão. Ele
percebeu que ela estava certa: "o fantasma
do livro destruído iria assombrar meus ar-
quivos para o resto da minha vida" (BOYD,
1991, p. 170, tradução nossa).

Em terceiro lugar, e mais importante, a noção de incompletude que perseguiu Nabokov até o túmulo. O inacabado $L o$ lita, de 1950 (que viria a ser lançado somente cinco anos mais tarde), o inacabado "Fogo pálido", poema de John Shade, e o inacabado $O$ original de Laura. Sabia- 
-se da existência das fichas manuscritas de $O$ original de Laura desde a morte de Nabokov. Apesar do seu pedido à esposa, Vera não teve coragem de queimar os originais, guardando-os consigo até a data de sua morte, em 1991, quando passaram ao poder de Dmitri Nabokov, filho do escritor. Entre lendas e falsas pistas das bem guardadas fichas catalográficas escritas a lápis, Dmitri, em 2008, faz um acordo milionário com editoras dos EUA e da Inglaterra e $O$ original de Laura é publicado no ano seguinte, violando a última vontade de Nabokov. Nem se pode dizer que o "livro" está incompleto; trata-se apenas de anotações e esboços para a escrita definitiva do romance. $\mathrm{O}$ fato de se chamar $O$ original de Laura, aliás, é parte dessa estranha aleatoriedade de eventos que tocam uns aos outros: o apropriadíssimo título fora dado pelo próprio Nabokov, e seria de fato o título do romance, caso tivesse sido concluído.

A ligação pelo inacabamento entre os três eventos, e especialmente entre ficção e realidade, entre criador e criatura, inaugura um hipertexto de possibilidades interessantes ao se pesquisar Nabokov. Das muitas questões que cercam Fogo pálido, a mais pertinente é, sem dúvida, a do narrador. Quantas são as vozes no romance? E quais são seus donos? Charles Kinbote realmente existiu?

Há de se contextualizar os três grandes acontecimentos na interpretação de Fogo pálido para a crítica mundial. $\mathrm{O}$ primeiro ocorreu logo no ano de seu lançamento, em 1962, em proposta formu- lada por Mary McCarthy em um ensaio chamado A bolt from the blue. Segundo McCarthy (apud ROSENBAUM, 1999b), Kinbote seria a invenção de um personagem secundário no romance: V. Botkin, um colega na universidade onde John Shade lecionava. Essa versão perdurou pacificada por quase 30 anos, quando Brian Boyd, com acesso a arquivos e diários de Nabokov, elabora uma segunda conjetura: a de que John Shade inventou Kinbote, forjou sua morte e, portanto, escreveu tanto o poema quanto o prefácio, o comentário e o índice. Essa versão foi muito bem aceita e tornou-se referência por toda a década de 90 , até o próprio Brian Boyd refutá-la. Em Nabokov's pale fire: the magic of artistic discovery, de 1999, Boyd passa a argumentar que a escrita de Fogo pálido, na verdade, foi influenciada pelo fantasma de Hazel Shade, filha de John Shade, diretamente do além-túmulo. Essa versão é sustentada até hoje.

Segundo sua esposa Vera, em depoimento ao próprio Brian Boyd, a relação de Nabokov com a morte, e com o que há para além dela, foi uma constante na vida e na obra do escritor (iniciando-se com uma tragédia em sua juventude, abordada logo mais), e é, de fato, o que fica claro ao tocarmos os três pontos de referência em nossa linha do tempo. Lolita, Fogo pálido e todo o episódio referente à publicação de $O$ original de Laura (cujo título em seus primeiros rascunhos era Dying Is Fun) são atravessados pela presença da morte. Humbert passa toda 
a sua vida assombrado pelo fantasma de Annabel (seu coito interrompido de adolescente, morta "de tifo, em Corfu", quando ele tinha 12 anos), procurando-a em cada menina de 12 ou 13 anos, até substituí-la por Lolita, ainda mais terrível e ameaçadora (lembre-se de que Lolita é o relato de H.H., escrito na prisão, enquanto aguarda julgamento pelo assassinato de Clare Quilty, episódio que fecha o romance). Em Fogo pálido (que começa e termina pela mesma morte), há a opressão do suicídio de Hazel, que passa a atormentar John Shade. Já em $O$ original de Laura, a morte do próprio Nabokov, o fantasma de um pedido não realizado por 30 anos e, finalmente, o argumento (macabro, louco ou simplesmente cínico) dado por Dmitri para sua publicação: a visita do espírito de seu pai, que não apenas lhe concedeu carta branca como o aconselhou a ganhar quanto dinheiro conseguisse com o livro.

De algum modo, Nabokov sempre esteve envolto e compelido a atender ao chamado pálido dos seus fantasmas, que, embora comece tênue, quase inaudível, infla em persistência como o $L a ́$ que enlouqueceu Schumann. Curioso é esse chamado levar sempre ao lugar íntimo da autodestruição por três vezes violado: entre o fogo e os manuscritos. Talvez Nabokov não pudesse - talvez não quisesse - conter o ímpeto recorrente, feroz e nassariano, para "de pés descalços [...] incendiar o mundo!" (NASSAR, 1989, p. 106).
A cena em que John Shade queima as fichas de "Fogo pálido", testemunhada por Charles Kinbote, é, em si mesma, um espectro do passado e uma premeditação do futuro - um ponto convexo do tempo. Remonta à cena de 1950 , ao mesmo tempo em que profetiza o pedido de 1977. Como talvez Dmitri tenha feito recentemente (não cabem julgamentos, mas, mesmo assim, não se pode fugir à apreciação das travessuras do acaso), Kinbote roubou para si o trabalho do amigo, publicando-o incompleto mesmo, apesar da relutância de Shade, descrita no livro, em deixar qualquer um que não fosse sua mulher ler seu trabalho inacabado. Dmitri, de certa forma, foi o "Nabokov's Kinbote". Por isso o fantasma "visto" por Dmitri chama um segundo, visto por Kinbote: o próprio John Shade. Não a pessoa em si, mas a imagem, o ato e a memória. A cena que ele inadvertidamente presencia é um gesto do desejo do amigo, uma visão, de um futuro não acontecido, sobre o que deveria ser feito a seu poema, caso permanecesse inacabado.

Lembro-me bem de tê-lo visto de minha varanda, numa manhã brilhante, queimando uma grossa pilha de fichas no fogo pálido do incinerador diante do qual se mantinha de cabeça inclinada, como se participasse de um enterro solene, entre as boletas negras que o vento tangia naquele auto de fé de quintal (NABOKOV, 2004, p. 13).

Eis a mensagem na garrafa de John Shade, o homem que leva a sombra no nome, o único em Fogo pálido ao qual o narrador parece dispensar certa compaixão e uma admiração não dissimulada. 
Aquele que, como outro antes dele, fora assassinado, também a tiros e também por engano: o pai de Nabokov. Vladimir tinha apenas 22 anos.

Ainda que este breve estudo tenha de se encerrar com uma nota ao trágico, parece-nos apropriada a sugestão de que, para o inacabamento da obra, tenha servido de inspiração o inacabamento do homem.

\section{Considerações finais}

Vimos, de acordo com nosso marco teórico, que a noção do incompleto anda lado a lado com a vida, a morte e a literatura de Nabokov. Analisamos fatos históricos e intercâmbios da realidade para a arte que, quando não configuram coincidências incríveis, deixam a suspeita de que a fonte da qual Nabokov bebia para alimentar sua obra estava há muito contaminada com a ideia da morte - morte da carne, do sentimento, da arte, todas convergentes para um ponto terrível no balanço das coisas humanas: o esquecimento. A sentença do fogo que Nabokov tentou, sem sucesso, aplicar aos originais de seu futuro Lolita (e sem sucesso, também, a $O$ original de Laura), gesto que seria mais tarde incorporado à trama de Fogo pálido, é a sentença do esquecimento, da rasura de memórias. Assombra Nabokov a ideia da literatura incompleta, do livro aberto, como assombram os amores inacabados de seus personagens.

Porque é pelo inacabamento que cavalgam os fantasmas de Nabokov. A obsessão pelo último detalhe concebível, pela última palavra, e a frustração ao se constatar a verdade na prescrição de Bakhtin: não há última palavra, não há acabamento, apenas um mantra sempiterno do qual tanto fazem parte a mais insignificante resenha de jornal quanto a maior das obras-primas. O caráter estruturalmente hipertextual de Fogo pálido disfarça, em verdade, seu hermetismo: a liberdade do leitor estará associada sempre à porção exata de liberdade a ele prescrita pelo escritor, o que abre consideração para um caráter outro, talvez ainda mais importante: a natureza de lemniscata da literatura, da internet, do dialogismo, do próprio hipertexto; o encontro frontal com esses estatutos infinitos guardados na delicada espiral de uma concha.

A lemniscata é o símbolo não oficial da eternidade; uma curva algébrica, fechada, que cruza com ela mesma. Aparece duas vezes em Fogo pálido, no poema (usada na descrição de uma memória de infância) e no "Comentário", onde Kinbote acusa Shade de haver sucumbido ao "encanto da eufonia falaciosa". "Suspeito que a frase de Shade não tenha nenhum sentido real" (2004, p. 132), afirma Kinbote. Originada de uma fórmula matemática, a lemniscata parece conveniente para se ilustrar o dialogismo e o hipertexto: um circuito, um uróboro, um percurso infindo que estamos todos condenados a repetir.

$\mathrm{O}$ inacabamento quase procedido no atentado frustrado a Lolita, o inacabamento simbólico do poema de 999 versos "Fogo Pálido" e o inacabamento literal de $O$ original de Laura projetam, 
num equilíbrio raro entre a ficção e a realidade, a eternidade da arte contra a finitude da vida. A morte de Nabokov antes de concluir $O$ original de Laura, assim como a morte de John Shade antes de concluir "Fogo pálido", faz lembrar que o inconcluso é uma maldição comum a todos, ainda que apenas aos gênios seja regalado desfrutar de lamentação alheia. A falta que os grandes fazem (em cinema, pintura, literatura...) sempre refulgirá neste que é o mais perverso dos inacabamentos: quando a vida do homem fica pequena para a grandeza do artista.

I had a favorite young shagbark there With ample dark jade leaves and a black, spare, Vermiculated trunk. The setting sun Bronzed the black bark, around which, like undone Garlands, the shadows of the foliage fell. It is now stout and rough; it has done well. White butterflies turn lavender as they Pass through its shade where gently seems to sway The phantom of my little daughter's swing. - Vladimir Nabokov

\section{Pale fire and the incompleteness}

\section{Abstract}

This paper explores the notions of incompleteness from the novel Pale fire (2004), by Vladimir Nabokov (1994, 2004, 2009, 2010), component of the corpus of our research. As theoretical mark we took the Mikhail Bakhtin's (1997) dialogism, such as the postulations of Pierre Lévy (1998, 2002) about the hypertext. The research is descriptive and qualitative. The incompleteness is approached by different - although converging - viewpoints. Will be spoken of the incompleteness as inherent aspect of dialogism and hypertext, the literal incompleteness of the thinking of Bakhtin (which leads to the own philosophy's incompleteness that is necessary to be always continued by reading), the unfinished work of Nabokov (whose latest book, The original of Laura 2009, remained incomplete) and the incompleteness discussed in Pale fire, as the same idea of unfinished refracts in different angles to recombine, finally, in the face of a common synthesizer: the infinity.

Keywords: Incompleteness. Hypertext. Dialogism.

\section{Notas}

1 Citação de texto corrido retirada de página única disponível na internet.

2 Citação de texto corrido retirada de página única disponível na internet.

3 Nabokov era veemente tanto ao destacar o quão brilhante era Ulysses, em sua opinião o grande romance do séc. XX, quanto ao criticar Finnegans wake, que chamou, em entrevista publicada em 1967 no Wisconsin Studies in Contemporary Literature, de "formless and dull mass of phony folklore". As opiniões extremas de Nabokov sobre James Joyce sugerem certo misto de inspiração e rivalidade do russo em relação ao irlandês. O dado mais notável, além de suas aulas de literatura em Cornell e Princeton, foi a aparição explícita de Finnegans wake em Fogo pálido - claro que de modo negativo. "Com certeza, seria impróprio para um monarca apresentar aos jovens de faces rosadas o Finnegans wake como monstruosa extensão das 'transações incoerentes' de Angus MacDiarmid [...]" (NABOKOV, 2004, p. 78).

4 Indeed, when an interviewer asked Nabokov a question about October 19, the date on which Kinbote signs his Foreword, he identified it as "the day on which Kinbote committed suicide (and he certainly did after putting last touches to his edition of the poem)". Michael Wood regards this as "authorial trespassing", and comments: "We don't have to pay attention to it".

5 Citação de texto corrido retirada de página única disponível na internet. 
6 Citação de texto corrido retirada de página única disponível na internet.

7 Há de se recordar: entre Lolita e seu livro anterior, A verdadeira vida de Sebastian Knight, há um hiato de 14 anos. Como dados adicionais, o fato de Nabokov ser um imigrante russo nos EUA em plena paranoia nuclear e de ter passado uma década e meia dando aulas de literatura para sobreviver. Apesar dos dez livros escritos nas décadas de 20 e de 30 , Nabokov só conheceu o sucesso com Lolita, em 1955, aos 56 anos de idade.

8 Even the financial considerations would surely compel him to write something else that he could sell to the New Yorker. Perhaps the time had come to abandon the whole thing. Despondent, he carried his pile of index cards out to the garden incinerator leaning in the grass at the back of 802 East Seneca Street. At the point, fortunately for Nabokov and for literature, his wife stopped him and urged him to think it over again. He realized she was right: "the ghost of the destroyed book would haunt my files for the rest of my life".

\section{Referências}

BAKHTIN, Mikhail. Estética da criação verbal. São Paulo: Martins Fontes, 1997.

BORGES, Jorge Luiz. Ficções. São Paulo: Companhia das Letras, 2007.

. O livro de areia. São Paulo: Companhia das Letras, 2009.

BOYD, Brian. Vladimir Nabokov: the american years. Princeton: Princeton University Press, 1991.

. Nabokov's Pale Fire: the magic of artistic discovery. Princeton: Princeton University Press, 1999.

CHARAUDEAU, Patrick; MAINGUENEAU, Dominique. Dicionário de análise do discurso. São Paulo: Contexto, 2008.

CORTAZAR, Julio. O jogo da amarelinha. Rio de Janeiro: Civilização Brasileira, 2009.

FOUCAULT, Michel. Vigiar e punir. 26. ed. Petrópolis: Vozes, 1987.
LÉVY, Pierre. Tecnologias intelectuais e modos de conhecer: nós somos o texto. 1998.

Disponível em: <http://www.caosmose.net/ pierrelevy/nossomos.html>. Acesso em: 28 nov. 2012.

Tecnologias intelectuais e os modos de conhecer: nós somos texto. Primeira versão, Porto Velho, v. 1, n. 44, p. 2-8, 2002. Disponível em: <http://www.primeiraversao. unir.br/atigos_pdf/numero044Levy.pdf $>$. Acesso em: 28 nov. 2012.

MACHADO, Irene. Inacabamento como modelo artístico de mundo. Bakhtiniana, São Paulo, v. 1, n. 3, p. 82-98, 2010.

NABOKOV, Vladimir. Lolita. São Paulo: Companhia das Letras, 1994.

Fogo pálido. São Paulo: Companhia das Letras, 2004.

O original de Laura. Rio de Janeiro: Alfaguara, 2009.

A verdadeira vida de Sebastian Knight. Rio de Janeiro: Alfaguara, 2010.

NASSAR, Raduan. Lavoura Arcaica. São Paulo: Companhia das Letras, 1989.

NUTO, João Vianney Cavalcanti. O pensamento de Mikhail Bakhtin na atualidade. 2009. Disponível em: <http://conversasbakhtinianas.blogspot.com.br/2009/10/o-pensamento-de-mikhail-bakhtin-na.html>. Acesso em: 28 nov. 2012.

ROSENBAUM, Ron. Nabokov's pale ghost: a scholar retracts. 1999a. Disponível em: $<$ http://observer.com/1999/04/nabokovs-pale-ghost-a-scholar-retracts/>. Acesso em: 28 nov. 2012.

The novel of the century: Nabokov's Pale Fire. 1999b. Disponível em: <http:// observer.com/1999/12/the-novel-of-the-century-nabokovs-pale-fire/>. Acesso em: 28 nov. 2012. 